\title{
The History of Reception of Charles S. Peirce in Greece
}

Christos A. Pechlivanidis

\section{OpenEdition}

1 Journals

Electronic version

URL: http://journals.openedition.org/ejpap/503

DOI: 10.4000/ejpap.503

ISSN: 2036-4091

Publisher

Associazione Pragma

\section{Electronic reference}

Christos A. Pechlivanidis, "The History of Reception of Charles S. Peirce in Greece », European Journal of Pragmatism and American Philosophy [Online], VI-1 | 2014, Online since 08 July 2014, connection on 17 March 2020. URL : http://journals.openedition.org/ejpap/503 ; DOI : https://doi.org/10.4000/ejpap. 503

This text was automatically generated on 17 March 2020.

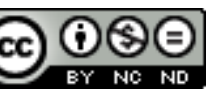

Author retains copyright and grants the European Journal of Pragmatism and American Philosophy right of first publication with the work simultaneously licensed under a Creative Commons AttributionNonCommercial-NoDerivatives 4.0 International License. 


\title{
The History of Reception of Charles S. Peirce in Greece
}

\author{
Christos A. Pechlivanidis
}

\section{AUTHOR'S NOTE}

This research has been co-financed by the European Union (European Social Fund ESF) and Greek national funds through the Operational Program "Education and Lifelong Learning" of the National Strategic Reference Framework (NSRF) - Research Funding Program: THALIS - UOA "Aspects and Prospects of Realism in the Philosophy of Science and Mathematics" (APRePoSMa).

1 Despite the great interest on Peirce's work in Europe especially from the 1960s onwards, Peirce's name in Greek literature could be found only in introductory books of philosophy and in particular in those concerned with the theory of language. An exception is Evangelos Papanoutsos' Pragmatism or Humanism: Elaboration and Criticism of the Theories of a Great Current of Contemporary Philosophy (Papanoutsos 1924), which studies pragmatism as it had been shaped mainly by F. C. S. Schiller. References to Peirce by the Member of the Academy of Athens Evangelos Moutsopoulos and professor of philosophy Georgios Mourelos follow the main trend which connects Peirce's pragmatism with practical - and in many respects - shallow thought. Undoubtedly, the first notable attempt to study Peirce takes place in 1980 with Demetra SfendoniMentzou's doctoral dissertation titled "Probability and Chance in C.S.Peirce's Philosophy" (in Greek) with which she produced the first systematic analysis of one aspect of Peirce's work into the Greek philosophical literature.

2 Her dissertation aims to provide a unitary reconstruction of Peirce's scattered writings on probability and chance. The goal of the author is twofold: (a) to show that Peirce's theory of chance is intimately related to his theory of probability and should not be treated as belonging mainly to metaphysical and cosmological speculation and (b) to study Peirce's ideas on probability and chance in the context of contemporary 
philosophy of science, so as to show the pioneering character of Peirce's Tychism in relation to the idea of indeterminacy of Quantum Mechanics (Sfendoni-Mentzou 1980).

The continuation of this valuable work can be found in D. Sfendoni-Mentzou's paper "The Dynamic Character of C.S. Peirce's Pragmatic Theory of Meaning" (in Greek) published in Philosophia in 1982. In this paper, the author explores the formulation of Peirce's late pragmaticism, in which the concepts of purpose and possible outcomes become central. The author suggests that these two notions ascribe to the theory of meaning a dynamic character, in which Thirdness, and in particular the concepts of generality and potentiality, come to have a fundamental role (Sfendoni-Mentzou 1982).

4 As a result, in the academic year 1982-83 she introduced courses on Peirce's pragmatic theory of meaning and truth in the program of the Department of Philosophy of the Aristotle University of Thessaloniki. Since 1996, she has claimed in her introductory graduate course on "Theories of Knowledge" that Peirce's pragmatism represents a third and more fruitful solution to the traditional opposition between the rationalism of Descartes and the empiricism of the British empiricists.

In 1982, two of Peirce's short essays are translated and published in Greek in the journal Signum, i.e. the "Logic and Liberal Education" by Pantelis Nikolakopoulos and the "Definition and Function of a University" by Konstantinos Antonopoulos. Two years later, in 1984, D. Sfendoni-Mentzou publishes in Greek the first complete study on Peirce's pragmatism, under the title The Philosophy of C. S. Peirce's Pragmatism. How to Make Our Ideas Clear (Sfendoni-Mentzou 1984). This also includes her translation into Greek of Peirce's fundamental article, "How to Make Our Ideas Clear."

6 Another important paper on Peirce appears in 1986 by D. Sfendoni-Mentzou under the title "C. S. Peirce's Theory of Signs: Semiotics, Ontology, Hermeneutics" (in Greek), Proceedings of the 1st Philosophical Workshop: The Philosophical Hermeneutics. In this paper the author shows that Peirce's theory of signs enters every aspect of his work and investigates the emphasis given by Peirce to the "interpretation community" as a "collective knowing subject" (Sfendoni-Mentzou 1986).

7 In 1989 Sfendoni-Mentzou participates in the C.S. Peirce Harvard Sesquicentennial Congress with two papers. The first one is "The Role of Potentiality in Peirce's Tychism and in Contemporary Discussions in Quantum Mechanics and Microphysics" (SfendoniMentzou 1993a). In this paper, Peirce's views on probability and chance, which she studied in detail in her doctoral dissertation, are presented in relation to Quantum Mechanics and Aristotle's idea of potentiality. The second one is "A Response to D. Savan's 'Peirce and Idealism”' (Sfendoni-Mentzou 1995). In her remarks on D. Savan's position on the issue of Peirce's idealism as well as in her article, "Towards a PotentialPragmatic Account of Peirce's Theory of Truth" (Sfendoni-Mentzou 1991), one can find her over-all approach to Peirce's theory of truth considered in close connection to that of reality.

8 Since 1997 D. Sfendoni-Mentzou has published a variety of papers in Greek and international scientific journals and collective volumes where she analyses her ideas on Peirce's pragmatic-realist philosophy. Her sophisticated version of realism is enriched with Aristotle's conception of the physical world and scientific knowledge. In all these papers she argues for a more spherical and fertile picture of the scientific enterprise as an answer to the anti-realist reading of science. Furthermore, her papers on Peirce's idea of abduction, the logic of scientific discovery, and such concepts as theoretical entities, laws of nature and time, represent a groundbreaking work in Greek language 
on the relevance of Peirce for the philosophy of science. This work began with her "Is there a Logic of Scientific Discovery? A Pragmatic-Realist Account of Rationality in Physical Theory," which appeared in the Proceedings of the First Greek-Soviet Symposium on Science and Society, and "Realism and Anti-Realism in the Philosophy of Science" which appeared in the Proceeding of the Beijing International Conference.

In 2009 Stathis Psillos' paper "An Explorer upon Untrodden Ground: Peirce on Abduction" analyses Peirce's two-dimensional approach to reasoning and focuses in particular on that specific form of inference called abduction (Psillos 2009).

On this basis, my paper "The Abductive Character of Science and the Dynamics of Discovery: Aristotle, Charles S. Peirce and Ernan McMullin" attempts to argue that the method of abduction, already discussed by Aristotle, is developed on different grounds and in a dynamic way by Peirce. This original form of reasoning has the peculiarity of being explanatory and fertile, qualities strongly connected to innovation in the scientific enterprise. Ernan McMullin borrows this idea from Peirce and goes on to establish his sophisticated version of abduction, which he calls retroduction, a term borrowed again from Peirce. McMullin explains that retroduction is the reasoning moving from observed effects backwards to the unobserved and often unobservable causes of the effects. This ampliative reasoning is the keystone of McMullin's retroductive strategy in his attempt to develop a fruitful method for finding what lies behind the phenomena (Pechlivanidis 2011).

The ideas developed in this paper are included in my doctoral dissertation "Ernan McMullin's Scientific Realism and its Aristotelian Origins" published in 2013 in Greek under the title Aristotle and Ernan McMullin: Tracking the Roots of Contemporary Scientific Realism (Pechlivanidis 2013a).

Some years before, Aristides Gogoussis' doctoral dissertation "The Problem of Engineering Design of Operation in Philosophy of Technology and Contribution to its Resolution" analyses Henry Paynter's proposal and development of the bond-graphs approach to system dynamics modeling. In his work, Gogoussis argues that Paynter is deeply influenced by Peirce. In particular, he claimed that Peirce's realization of the importance of the triadic structural occurrence as a source of great potential for variety in nature led Paynter to the conception of two complementary power nodes (Gogoussis 2002). One year later, Grigoris Karafyllis publishes in Greek a paper on Peirce's and Dewey's philosophical conceptions of educational theory (Karafyllis 2003).

In the same period there are also some significant studies on Peirce and language. The linguist Tassos Christidis offers an important account of Peirce's semiotics. Maria Theodoropoulou remarks that "Peirce's semiotic taxonomic distinction into index, icon, and symbol, and the corresponding Peircean categories of Firstness, Secondness, and Thirdness, serve among others as valuable sources from which Christidis draws critically in order to demonstrate and support his own view about the nature of language" (Theodoropoulou 2008). In Christidis' words, "Peirce's analysis of signs has been the fullest and deepest account of the phenomenology of semiosis" (Christidis 2001).

Finally, it is worth mentioning the appearance in 2012 of the 2nd edition of D. SfendoniMentzou's book Pragmatism - Rationalism - Empiricism. Theories of Knowledge (1st ed. 2004), perhaps the most important study on Peirce published in Greek. The book focuses on Charles S. Peirce's pragmatic theory of knowledge, meaning and truth, on Peirce's critic of traditional epistemological systems of Rationalism and Empiricism, and on his contribution in providing a solution to the problem of knowledge. This book 
is an original and valuable contribution to the Greek and international research on Peirce as it sheds light on Peirce's realism in its connection with his theory of knowledge and his deep affinity to Aristotle (Pechlivanidis 2013b).

\section{BIBLIOGRAPHY}

CHRISTIDIS A. F., (2001), "The Nature of Language" (in Greek), in A history of Greek Language: From the beginnings to Late Antiquity, Thessaloniki, The Institute of Modern Greek Studies (Manolis Triandaphyllidis Foundation), 21-52.

GOGoussis A., (2002), The Problem of Engineering Design of Operation in Philosophy of Technology and Contribution to its Resolution, Doctoral Thesis (in Greek), Thessaloniki, Aristotle University of Thessaloniki.

KARAFYLLIS G., (2003), "Philosophical Conceptions of Charles Peirce and John Dewey for Educational Theory" (in Greek), Social Sciences Tribune 20 (36), 127-56.

PAPANOUTSOS E., (1924), Pragmatism or Humanism: Elaboration and Criticism of the Theories of a Great Current of Contemporary Philosophy (in Greek), Athens, Grammata editions.

PECHLIVANIDIS C. A., (2011), “The Abductive Character of Science and the Dynamics of Discovery: Aristotle, Charles S. Peirce and Ernan McMullin" (in Greek), History, Philosophy and Didactics of Sciences 23, 127-37.

PECHLIVANIDIS C. A., (2013a), Aristotle and Ernan McMullin. Tracking the Roots of Contemporary Scientific Realism (in Greek), Thessaloniki, Ziti editions.

PECHLIVANIDIS C. A., (2013b), Review of: D. Sfendoni-Mentzou, Pragmatism - Rationalism - Empiricism. Theories of Knowledge (in Greek, 2nd upgraded and enlarged edition, Thessaloniki, Ziti editions, 2012), Philosophia 43, 487-88.

PSILLOS S., (2009), “An Explorer upon Untrodden Ground: Peirce on Abduction,” in Handbook of the History of Logic, Vol. 10 (Inductive Logic), Amsterdam, Elsevier BV, 117-51.

SFENDONI-MENTZOU D., (1980), Probability and Chance in the Philosophy of C. S. Peirce, Doctoral Thesis (in Greek), Thessaloniki, Aristotle University of Thessaloniki.

SFENDONI-MENTZOU D., (1982), “The Dynamic Character of C. S. Peirce's Pragmatic Theory of Meaning” (in Greek), Philosophia 12, 359-78.

SFENDONI-MENTZOU D., (1984), The Philosophy of C. S. Peirce's Pragmatism. How to Make Our Ideas Clear (in Greek), Thessaloniki, Sakkoula Publications.

SFENDONI-MENTZou D., (1986), “C. S. Peirce's Theory of Signs: Semiotics, Ontology, Hermeneutics” (in Greek), Proceedings of the 1st Philosophical Workshop: The Philosophical Hermeneutics, Thessaloniki, Greek Philosophical Society \& Department of Philosophy-A.U.Th, 130-39.

SFENDONI-MENTZou D., (1991), “Towards a Potential-Pragmatic Account of C. S. Peirce's Theory of Truth," Transactions of the C. S. Peirce Society 27 ( 1), 27-77. 
SFENDONI-MENTZOU D., (1992), "Is there a Logic of Scientific Discovery? A Pragmatic-Realist Account of Rationality in Physical Theory," in Historical Types of Rationality. Proceedings of the First GreekSoviet Symposium on Science and Society, Vol. VIII, Athens, National Technical University of Athens, 239-50.

SFENDONI-MENTZou D., (1993a), “The Role of Potentiality in C. S. Peirce's Tychism and in Contemporary Discussions in Quantum Mechanics and Micro-Physics," in Charles S. Peirce and the Philosophy of Science: Papers from the 1989 Harvard Conference, Tuscaloosa, The University of Alabama Press, 246-61.

SFENDONI-MENTZOU D., (1993b), “The Reality of the Unobservable in Physical Theory: An Account of C. S. Peirce's Pragmatic Realism," Reflex $\alpha$ 57, 103-18.

SFENDONI-MENTZOU D., (1995), "Peirce and Idealism: Response to Savan," in Peirce and Contemporary Thought. Philosophical Inquiries, New York, Fordham University Press, 329-38.

SFENDONI-MENTZOU D., (1996), “The Reality of Thirdness: A Potential-Pragmatic Account of Laws of Nature," in Realism and Anti-realism in the Philosophy of Science, BSPS, Vol. 169, Dordrecht, Kluwer, 75-97.

SFENDONI-MENTZOU D., (1997), "Peirce on Continuity and Laws of Nature," in Transactions of the Charles S. Peirce Society, Vol. 33, No. 3, Bloomington, IN, Indiana University Press, 591-645.

SFENDONI-MENTZou D., (2008), “C. S. Peirce and Aristotle on Time,” COGNITIO. Revista de Filosofia 9 (2), 261-80.

SFENDONI-MENTZOU D., (2012), Pragmatism - Rationalism - Empiricism. Theories of Knowledge (in Greek), 2st upgraded and enlarged edition (1st ed. 2004), Thessaloniki, Ziti editions.

THEODOROPOULOU M., (2008), Light und Wärme. In Memory of A. F. Christidis (in Greek and in English), Thessaloniki, Centre for the Greek Language.

\section{AUTHOR}

\section{CHRISTOS A. PECHLIVANIDIS}

Aristotle University of Thessaloniki, Greece

chpechli[at]edlit.auth.gr 